\title{
Sublethal Effects of Crude Oil and Chemical Dispersants on Multiple Life History Stages of the Eastern Oyster, Crassostrea virginica
}

\author{
Sara M. Garcia, Kevin T. Du Clos ${ }^{D}$, Olivia H. Hawkins and Brad J. Gemmell *D \\ Department of Integrative Biology, University of South Florida, Tampa, FL 33620, USA; \\ saramgarcia18@gmail.com (S.M.G.); duclos@uoregon.edu (K.T.D.C.); \\ ohawkin1@students.kennesaw.edu (O.H.H.) \\ * Correspondence: bgemmell@usf.edu
}

Received: 13 September 2020; Accepted: 13 October 2020; Published: 19 October 2020

check for updates

\begin{abstract}
The eastern oyster Crassostrea virginica is an ecologically and economically important species that is vulnerable to oil pollution. We assessed sublethal effects of soluble fractions of crude oil alone (WAF) and crude oil in combination with Corexit 9500 dispersant (CEWAF) on oysters at three life history stages. Veliger swimming, pediveliger settlement, and adult clearance rates were quantified after $24 \mathrm{~h}$ exposures to the contaminants. Veliger swimming speeds were not significantly impacted by $24 \mathrm{~h}$ exposures to WAF or CEWAF. A larger proportion of veligers were inactive following WAF and CEWAF exposure as compared to the control, but the effect was greater for pediveligers, and pediveliger settlement in the highest concentration CEWAF treatment decreased by $50 \%$ compared to controls. Thus, pediveligers may be particularly vulnerable to oil exposure. In the adults, we found significant clearance rates reductions that persisted 33 days after acute exposure to CEWAF. Knowledge of sublethal effects of oil and dispersant at multiple life history stages aids understanding of how this important species will respond to an oil spill.
\end{abstract}

Keywords: larvae; settlement; clearance rate; Corexit; veliger; pediveliger

\section{Introduction}

Offshore oil spills, such as the Deepwater Horizon (DWH) spill that occurred from 20 April to 15 July of 2010 in the Gulf of Mexico, have wide ranging impacts. Due to the semi-enclosed nature of the Gulf of Mexico and prevailing currents, surface and subsurface oil were distributed over large distances and impacted over $2100 \mathrm{~km}$ of coastline [1,2]. During the DWH spill, an estimated $7.2 \times 10^{6} \mathrm{~L}$ of chemical dispersants (Corexit 9500 and Corexit 9527) was employed as traditional surface applications as well as $2 \times 10^{6} \mathrm{~L}$ subsurface at the well-head [1,3]. These powerful surfactants alter the chemical and physical components of oil, reducing the surface tension between oil and water, and allow the oil to be emulsified and dispersed in the water column more easily with sufficient wave energy [4]. While these methods enhance the effectiveness of oil dispersal, they also increase the persistence of soluble crude oil fractions, such as polycyclic aromatic hydrocarbons (PAHs), in the water column [5,6]. Once emulsified, the small droplets are unable to re-coalesce, increasing interactions of microdroplets with planktonic organisms or sessile organisms that feed on small particulates [1].

Sessile species are particularly at risk for exposure during an oil spill. One such species is the eastern oyster (Crassostrea virginica). These animals live within shallow subtidal and low intertidal coastal zones [7], making them vulnerable to oiling during a spill. Oysters are typically found in large, structurally complex reefs [8] that provide hard substrate for recruitment [9] and increase biodiversity by offering habitat for many other organisms [10]. Oysters and other bivalves are an important link in 
estuarine food webs and are consumed by resident crab, fish, and bird species [11-13]. In addition to the oyster's ecological contributions, they are an important economic driver for coastal communities, with annual landings in the United States of approximately $\$ 17.3$ million $[1,14]$. The ecological and economic value of oysters underlies the importance of understanding the effect of oil pollution on this species.

The DWH blowout coincided with the C. virginica's spawning season in the northern Gulf of Mexico [15-17], suggesting multiple life history stages may have been affected. Like other bivalves, C. virginica has a planktonic larval veliger stage that transitions to a pediveliger stage, which settles and metamorphoses into a sessile adult oyster [18]. As adults, oysters are effective filter feeders that remove plankton and suspended sediments from the water column, improving water clarity and quality $[19,20]$. Compared to adults, early developmental stages of marine invertebrates are generally more sensitive to crude oil exposure [21]. Exposure to oil pollution can cause a variety of adverse effects in larvae, including narcosis [21] and decreased growth [15,16,22-24]. Additionally, the presence of chemical dispersants has been found to increase toxicity up to 52-fold [25]. Sublethal exposures to PAHs have also been shown to have metabolic costs for adult bivalves [26].

While a number of studies have examined effects of crude oil and/or chemical dispersant exposure on oyster larvae $[15,16,27-31]$, many of these focused on developmental effects related to early exposures shortly after fertilization. In this study, we quantify behavioral effects of sublethal effects of crude oil with and without chemical dispersant on the eastern oyster (Crassostrea virginica) at multiple life history stages (from veliger to adult) immediately after exposure at discrete life history stages with environmentally realistic oil concentrations. We also explore the impact on adult feeding rates up to 30 days after acute exposures.

Here we address the effects of acute exposure to ecologically relevant concentrations of crude oil water accommodated fractions (WAF) and chemically enhanced water accommodated fractions (CEWAF) on: (1) veliger swimming kinematics (cruising speed, sinking speed, and total distance traveled), (2) pediveliger settlement, and (3) adult clearance rates. Results from this study will aid in our understanding of the biological impacts of crude oil pollution on an ecologically and economically important species, and may help to inform response decisions in the event of a future spill.

\section{Materials and Methods}

\subsection{Preparation of WAF and CEWAF}

All exposures used a Louisiana Light Sweet Crude oil that is a surrogate for the Macondo (MC252) crude oil released in the DWH oil spill [22,32]. PAH concentrations for each exposure were calculated from loading rates based on a previously published chemical analysis of the same stock ([22], Table 1). Corexit 9500A (Nalco/Exxon Energy Chemicals, L.P., Naperville, IL USA) was used as the chemical dispersant, as it was the primary dispersant used during remediation operations during the DWH oil spill. All experiments used artificial seawater (ASW), prepared at salinity 20 in deionized water (Instant Ocean).

Table 1. Crude oil concentrations in $\mu \mathrm{L} \mathrm{L}^{-1}$ and $\mathrm{mg} \mathrm{L}^{-1}$ and PAH concentrations in $\mu \mathrm{g} \mathrm{L}-1$ for each exposure, modified from Almeda et al. 2013 [22]. Abbreviations: Naphthalene (Nap), acenaphthene (Ace), acenaphthylene (Acy), fluorene (Flu), phenanthrene (Phe), anthracene (An), fluoranthene (Flua), pyrene (Pyr), benzo[a]anthracene (BaA), chrysene (Chr), benzo[b]fluoranthene (BbF).

\begin{tabular}{ccccccccccccc}
\hline \multicolumn{2}{c}{ [Crude Oil] } & \multicolumn{10}{c}{ [PAH] $\mu \mathbf{g ~ L}^{-\mathbf{1}}$} \\
\hline$\mu \mathbf{L ~ L ~ L}^{-\mathbf{1}}$ & mg L L $^{-\mathbf{1}}$ & Nap & Ace & Acy & Flu & Phe & An & Flua & Pyr & BaA & Chr & BbF \\
\hline 10 & 8.5 & 8.45 & 0.85 & 0.14 & 2.82 & 6.08 & 0.08 & 0.15 & 0.31 & 0.14 & 1.94 & 0.2 \\
25 & 21.1 & 21.12 & 2.14 & 0.35 & 7.06 & 15.21 & 0.2 & 0.38 & 0.77 & 0.35 & 4.85 & 0.49 \\
50 & 42.3 & 42.23 & 4.27 & 0.7 & 14.11 & 30.42 & 0.4 & 0.76 & 1.54 & 0.7 & 9.7 & 0.98 \\
100 & 84.5 & 84.46 & 8.54 & 1.4 & 28.23 & 60.83 & 0.8 & 1.53 & 3.08 & 1.4 & 19.39 & 1.96 \\
\hline
\end{tabular}


Water accommodated fraction (WAF) and chemically enhanced water accommodated fraction (CEWAF) treatments were prepared according to the Chemical Response to Oil Spills: Ecological Effects Research Forum (CROSERF) procedure [33]. For each treatment, three liters of ASW was circulated in a $4 \mathrm{~L}$ glass beaker on a stir plate using a magnetic stir bar. Treatments were brought to a vortex $25 \%$ of the depth of the beaker, and crude oil and chemical dispersant were added to produce the desired concentrations. The solution was allowed to mix at room temperature for $21 \mathrm{~h}$ and given $3 \mathrm{~h}$ to settle undisturbed [34-37]. For both WAF and CEWAF treatments, only the supernatant was used in experiments.

Exposures ranged from 10 to $100 \mu \mathrm{L}$ of crude oil per liter of water. These values are within the recorded range of crude oil concentrations (up to $710 \mu \mathrm{L} \mathrm{L}^{-1}$ ) detected historically in the water column $24 \mathrm{~h}$ after an oil spill [6,38]. Additionally, these concentrations are considered sublethal because they are well below the lethal concentrations $\left(215-1300 \mu \mathrm{L} \mathrm{L}^{-1}\right)$ detected for pediveligers after $24 \mathrm{~h}$ of exposure [29]. For CEWAF treatments, Corexit was added at a 20:1 oil to dispersant ratio, as recommended by the manufacturer.

\subsection{Veliger Swimming}

Crassostrea virginica larvae (6-8 days old) were obtained from Southern Cross aquaculture facility in Cedar Key, FL, USA and immediately transported back to the laboratory where they were maintained in two 20-L aquaria, fed with Isochrysis galbana, and gently aerated. Larvae were examined under a stereo microscope to ensure mobility prior to use in experiments. Two hundred veligers of similar size $(\sim 55 \mu \mathrm{m})$ were selected using a stereo microscope and transferred into $1 \mathrm{~L}$ glass bottles for experiments. Three replicates of each treatment were performed. Veligers were exposed for $24 \mathrm{~h}$ to WAF, CEWAF, or ASW then collected from each bottle by gently filtering through a $41-\mu \mathrm{m}$ mesh sieve and placed in a petri dish for analysis under a stereo microscope. Crude oil concentrations in the WAF and CEWAF treatments were 10,50 , and $100 \mu \mathrm{L} \mathrm{L}^{-1}$.

The number of recovered veligers per bottle was recorded and each was designated as active or inactive. A veliger was counted as active if it was swimming and inactive if it appeared to be non-responsive but still had an active heartbeat, as in Laramore et al. 2014 [29].

Active veligers from each condition were transferred to a glass filming cuvette $(45 \times 12.5 \times 52.5 \mathrm{~mm})$ containing clean ASW. A high-resolution camera (Edgartronic SC1) was used to record veliger swimming, and illumination was provided by infrared $(808 \mathrm{~nm})$ LED lighting in an otherwise unlit room so as not to influence the swimming behavior of these phototactic organisms. Each experimental vessel was filmed for a total of $60 \mathrm{~s}$ at a frame rate of 60 frames per second. Analysis of video recordings were performed using ImageJ software. The individual trajectories of swimming veligers ( $n=11-59$ per treatment) were measured and the mean cruising speed, sinking speed, and total displacement of identified trajectories were calculated using MATLAB. Cruising was defined as an instantaneous velocity $<2.0 \mathrm{~mm} \mathrm{~s}^{-1}$, sinking was defined as an instantaneous velocity $\geq 2.0 \mathrm{~mm} \mathrm{~s}^{-1}$, and total displacement included all displacement regardless of activity.

\subsection{Pediveliger Settlement}

Competent eyed pediveliger C. virginica larvae (18-21 days old) were obtained from Research Aquaculture Inc. in Tequesta, FL, USA and immediately transported back to the laboratory. Pediveligers were given $24 \mathrm{~h}$ to acclimate prior to experimentation. Two hundred pediveligers of similar size ( 200 $\mu \mathrm{m})$ were selected and transferred via soft pipette into $1 \mathrm{~L}$ glass bottles for experimental trials. Three replicates of each treatment were performed.

Pediveligers were exposed for $24 \mathrm{~h}$ to WAF, CWAF, or ASW, then gently collected onto a 320- $\mu \mathrm{m}$ mesh sieve and placed in a petri dish for analysis under a stereo microscope to determine whether each was active or inactive. Crude oil concentrations in the WAF and CEWAF treatments were 10 and $50 \mu \mathrm{L} \mathrm{L}^{-1}$. Active (swimming) individuals were then transferred to $20 \mathrm{~L}$ aquaria filled with $1.5 \mathrm{~L}$ of clean, artificial seawater. Ceramic tiles were placed on the bottom of the aquaria to allow a hard 
substrate for settlement. Larvae were gently aerated for $48 \mathrm{~h}$ to provide time for settlement. Isochrysis galbana (approximately 200 cells $\mathrm{mL}^{-1}$ ) was added daily as a food source. After $48 \mathrm{~h}$, pediveligers were filtered out with a $320 \mu \mathrm{m}$ mesh sieve and analyzed. The number of settled spat on each surface was recorded, as well as the numbers of swimming and inactive individuals remaining in each trial.

\subsection{Adult Clearance Rate}

Adult oysters were collected from Upper Tampa Bay Park in Tampa, FL, USA. Before experimentation, all algae, sediment, epiphytes, and fouling organisms (e.g., barnacles and other small oysters) were removed from the exterior of the shells. Oysters were given $24 \mathrm{~h}$ to acclimate to laboratory conditions before exposure to treatments.

For short-term $(24 \mathrm{~h})$ experiments, eighteen oysters of similar shell length (shell length mean 60, s.d. $12 \mathrm{~mm} ; n=6$ per treatment) were chosen. Animals were exposed to WAF, CEWAF, or ASW for $24 \mathrm{~h}$. Crude oil concentrations in the WAF and CEWAF treatments were 25, 50, and $100 \mu \mathrm{L} \mathrm{L}^{-1}$. After exposure, clearance rate tests were performed in either clean seawater or in the same water conditions as the $24 \mathrm{~h}$ exposure treatments.

Additionally, a longer-term study was conducted over 33 days after an acute 24-h exposure to determine rates of recovery from sublethal exposures. The crude oil concentration in this experiment was $100 \mu \mathrm{L} \mathrm{L}^{-1}$. Eighteen oysters (shell length mean 71 , s.d. $8 \mathrm{~mm} ; n=6$ per treatment) were exposed for $24 \mathrm{~h}$ to WAF, CEWAF, or ASW (control treatment), then marked and maintained together in clean ASW (salinity 20) in a $38 \mathrm{~L}$ aquarium, with recirculating filtration for the recovery portion of the experiment. Isochrysis galbana (approximately 1000 cells $\mathrm{mL}^{-1}$ ) was added daily as a food source. Clearance rate measurements were conducted on the same individuals in filtered seawater at 1,2,3,5, 12,19 , and 33 days after the initial exposure.

Clearance rate measurements were conducted in 1.5 L Carolina dishes with one oyster per dish. Oysters were allowed to acclimate for $30 \mathrm{~min}$ prior to the introduction of the microalgal food, as in Dupuy et al. 1999 [39]. Isochrysis galbana was introduced at approximately 1000 cells mL $\mathrm{m}^{-1}$ and water aliquots of $5 \mathrm{~mL}$ were taken from each dish at 0 and $30 \mathrm{~min}$. Aliquots were preserved in a $5 \%$ Lugol's Iodine solution for quantification. Oyster shell lengths were measured. Oysters were then shucked, internal tissues were removed, and wet tissue weights were recorded. Samples were transferred to a drying oven and allowed to dry for $36 \mathrm{~h}$ at $100{ }^{\circ} \mathrm{C}$ after which crucibles containing tissues were weighed and dry tissue weights calculated [40].

Cell counts of preserved Isochrysis galbana samples were completed using a $1 \mathrm{~mL}$ Sedgewick Rafter counting chamber. The size independent clearance rate $\left(F_{N W}, \mathrm{~L} \mathrm{~h}^{-1}\right)$ was calculated with the following equation:

$$
F_{N W}=\frac{\ln C_{0}-\ln C_{30}}{t-t_{0}} * V
$$

The initial $\left(C_{0}\right)$ and final $\left(C_{t}\right)$ concentration are recorded in number of cells per liter. The volume of suspension $(V)$ for experiments was $1.3 \mathrm{~L}$ and the amount of elapsed time $\left(t-t_{0}\right)$ was recorded in hours. Since the above clearance rate value $\left(F_{N W}\right)$ does not standardize the rates based on oyster size or weight, an additional calculation was required. Using dry weight, $W$, and a standardized constant used for clearance rate calculations, $b=0.73$ for the eastern oyster [41], a size specific clearance rate $\left(F_{W W}\right)$ was calculated for each condition and time point using the formula [39]:

$$
F_{W W}=\frac{F_{N W}}{W^{b}}
$$

\subsection{Statistical Analyses}

Statistical comparisons were made using one-way ANOVAs with Holm-Sidak Pairwise Test comparisons or a Student's $t$-test when only two groups were considered. In cases where only differences between controls and experimental groups were considered, the results of the Holm-Sidak 
Pairwise test are presented. Data from the long-term adult clearance rate experiment were tested using a two-way ANOVA. Significant differences were considered at $\alpha=0.05$. Normality of the data was confirmed using Shapiro-Wilks tests, and equal variance was confirmed using the Brown-Forsyth test.

\section{Results}

\subsection{Veliger Swimming}

Kinematic measurements on veligers revealed that exposure to environmentally relevant concentrations of soluble fractions of crude oil and Corexit 9500 had little impact on swimming capabilities after $24 \mathrm{~h}$. Oyster veligers undergo an alternating swim-sink activity pattern where these periods are distinctive from each other, differing greatly in speed. Sinking occurred at a magnitude approximately six-fold higher than swimming. Mean cruising speed of the control group $\left(0.467 \mathrm{~mm} \mathrm{~s}^{-1}\right.$ s.d. $0.232, n=57$ ) was not significantly different from any of the other treatment groups (one-way ANOVA, $p=0.06$; Figure 1A). Likewise for mean sinking speed, while the result of the one-way ANOVA was significant $(p=0.009)$ indicating significant differences between groups, there were no significant differences between the control group $\left(2.802 \mathrm{~mm} \mathrm{~s}^{-1}\right.$ s.d. $\left.0.704, n=46\right)$ and any of the other tested treatments (Figure 1B). The proportion of time that veligers spent cruising versus sinking also did not vary significantly between any of the experimental treatments. As a result, no significant differences in total displacement of swimming larvae were observed (one-way ANOVA, $p=0.09$; Figure 1C).
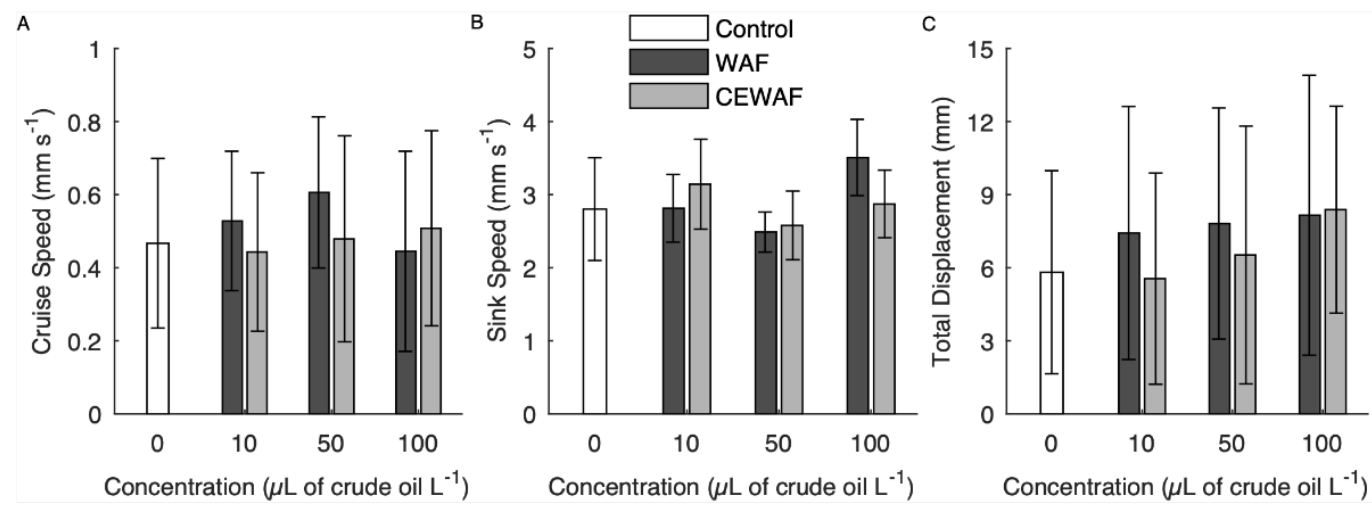

Figure 1. Mean (A) cruise speed (B) sink speed and (C) total displacement traveled of veligers ( $n \geq 30$ per treatment) after $24 \mathrm{~h}$ exposure to varying concentrations of WAF and CEWAF. An organism was considered cruising if its instantaneous velocity was $<2.0 \mathrm{~mm} \mathrm{~s}^{-1}$ and sinking if its instantaneous velocity was $>2.0 \mathrm{~mm} \mathrm{~s}^{-1}$. Error bars represent standard deviations.

\subsection{WAF/CEWAF Induced Inactivity}

Exposure to environmentally relevant concentrations of soluble fractions of crude oil (WAF) and Corexit 9500 (CEWAF) reduced activity of late-stage competent pediveligers more than early-stage veligers (Figure 2). The percentage of inactive veligers was expectedly low in the control treatments at $1.10 \%$ (s.d. $1.00, n=3$ ), but the mean inactivity was nearly an order of magnitude higher in the pediveliger control treatments at $9.60 \%$ (s.d. $2.30, n=3$ ). Inactivity in both developmental stages increased with WAF concentration, but the effect appeared to be more pronounced in pediveligers. This was evidenced by the fact that a one-way ANOVA $(p<0.01)$ showed significantly more inactive individuals than the control in all treatments $(p<0.01)$ at the pediveliger stage (Figure 2B), but a significant difference in inactivity was not observed at concentrations below $50 \mu \mathrm{L} \mathrm{L}^{-1}$ WAF at the veliger stage (ANOVA, $p=0.041$; Figure $2 \mathrm{~A}$ ). It should also be noted that in all comparable treatments (control, 10 and $50 \mu \mathrm{L} \mathrm{L}^{-1} \mathrm{WAF}$ and CEWAF), the inactivity of pediveligers was higher than that of the veligers. 


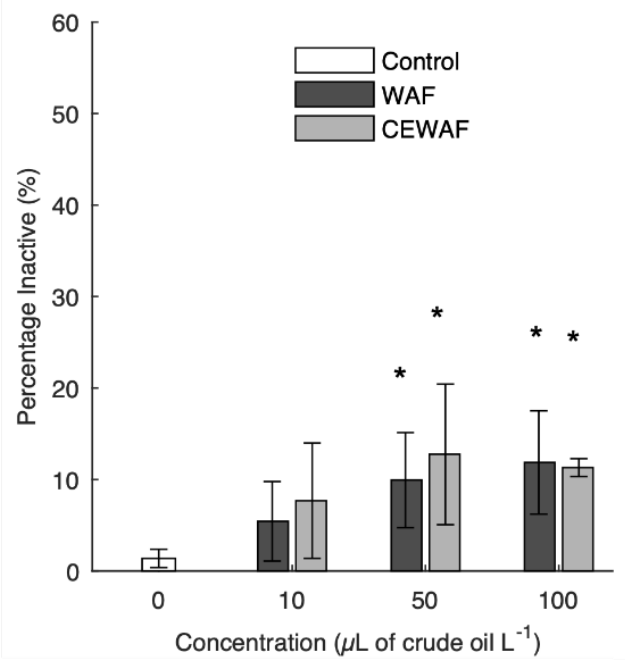

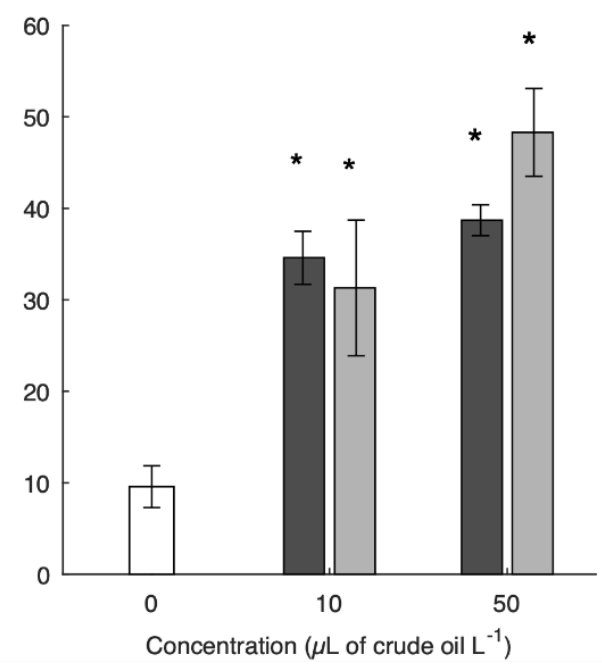

Figure 2. Mean percentage of $(\mathbf{A})$ veliger ( $n=3$ per treatment) and (B) pediveliger $(n=3$ per treatment) inactivity observed after $24 \mathrm{~h}$ exposures to varying concentrations of WAF and CEWAF. An organism was considered inactive if it was not swimming but had an active heartbeat. Error bars represent standard deviations. Stars $\left(^{*}\right)$ denote significant differences between controls and treatment.

\subsection{Pediveliger Settlement}

We observed the highest proportion of settlement in control and $10 \mu \mathrm{L} \mathrm{L}^{-1}$ WAF treatments, where mean settlement was $52.1 \%$ (s.d. $1.62, n=3$ ) and $51.4 \%$ (s.d. $5.56, n=3$ ), respectively. Results of one-way ANOVA $(p=0.023)$ indicated significantly lower sinking percentages in the $10 \mu \mathrm{L} \mathrm{L}^{-1}$ CEWAF treatment $(p=0.035)$ and the $50 \mu \mathrm{L} \mathrm{L}^{-1}$ WAF $(p<0.001)$ and CEWAF $(p<0.001)$ treatments (Figure 3$)$.

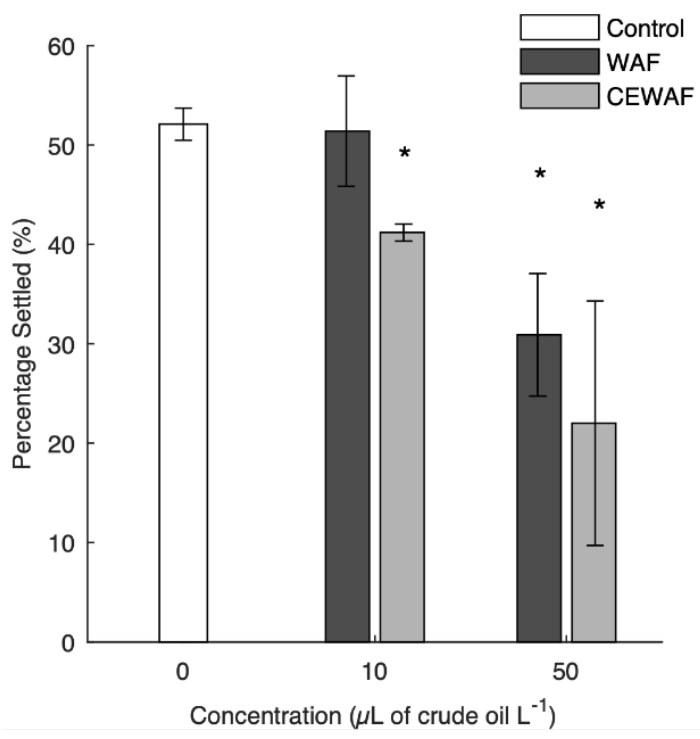

Figure 3. Pediveliger settlement percentages after organisms were given $48 \mathrm{~h}$ to settle after $24 \mathrm{~h}$ exposures to varying concentrations WAF $(n=3)$, CEWAF $(n=3)$, or clean seawater (control; $n=3)$. Settlement is presented as a percentage of total organisms. Error bars represent standard deviations. Stars $\left.{ }^{*}\right)$ denote significant differences between treatments and the control.

\subsection{Short-Term Adult Clearance Rates}

When clearance rates were measured in the same oil/dispersant conditions in which the oysters had been exposed for $24 \mathrm{~h}$, we generally observed a decrease in clearance rates for adult oysters compared to controls (Figure 4A). The clearance rate of WAF exposed oysters significantly decreased 
(ANOVA, $p=0.013$ ) only at an oil concentration of $100 \mu \mathrm{L} \mathrm{L}^{-1}$. Here the clearance rates went from $3.31 \mathrm{~L} \mathrm{~h}^{-1} \mathrm{~g}^{-1}$ (s.d. $0.90, n=6$ ) in control treatments to $2.01 \mathrm{~L} \mathrm{~h}^{-1} \mathrm{~g}^{-1}$ (s.d. $0.56, n=6$ ) in the WAF treatment. When chemical dispersant was added (CEWAF), significant decreases (ANOVA, $p=0.025$ ) in clearance rates were observed at both 50 and $100 \mu \mathrm{L} \mathrm{L}^{-1}$ oil concentrations (Figure 4A). However, the clearance rates of WAF and CEWAF exposed oysters were not significantly different from each other at any of the concentrations tested (ANOVA, $p=0.312$ ).
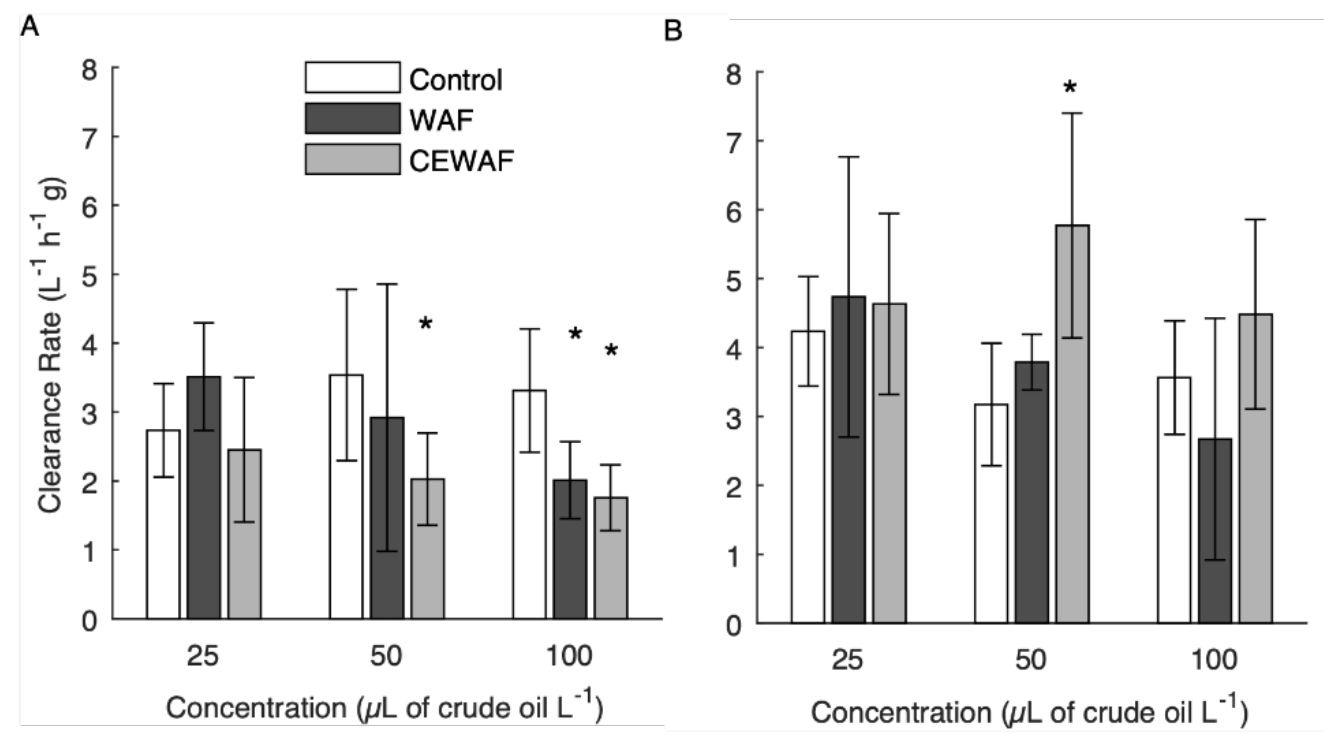

Figure 4. Mean short term clearance rate of WAF and CEWAF exposed oysters ( $n=6$ per treatment) in (A) oiled conditions and (B) clean seawater conditions. Adult oysters were initially exposed for $24 \mathrm{~h}$ to varying concentrations of WAF and CEWAF and immediately transferred to their respective feeding experiment. Error bars represent standard deviations. Stars $\left(^{*}\right)$ denote significant differences between controls and treatment.

When clearance rates were measured in clean seawater (no oil or dispersants) after a $24 \mathrm{~h}$ exposure, we generally observed no change or an increase in clearance rates compared to controls (Figure 4B). No significant differences in mean clearance rate were observed between control oysters and those exposed to WAF conditions at any of the concentrations tested (ANOVA, $p=0.287$ ). After exposure to CEWAF conditions and subsequent feeding in clean seawater, the mean clearance rates increased at all tested concentrations relative to controls but was only significantly higher at a 50 $\mu \mathrm{L} \mathrm{L}^{-1}$ oil concentration (ANOVA, $p=0.006$; Figure $4 \mathrm{~B}$ ). Here, control treatment clearance rates were $3.17 \mathrm{~L} \mathrm{~h}^{-1} \mathrm{~g}^{-1}$, (s.d. $0.889, n=6$ ) and the $50 \mu \mathrm{L} \mathrm{L}^{-1}$ CEWAF clearance rates $5.77 \mathrm{~L} \mathrm{~h}^{-1} \mathrm{~g}^{-1}$ (s.d. 1.63, $n=6)$.

\subsection{Long-Term Adult Clearance Rates}

To assess the extended impact of short-term oil/dispersant exposure on adult oysters, an additional experiment was performed using an oil concentration of $100 \mu \mathrm{L} \mathrm{L}^{-1}$. A two-way ANOVA showed a significant effect of treatment $(p<0.001)$ and a significant interaction between day and treatment $(p=0.01)$ but no significant effect of day $(p=0.14)$. The clearance rates of WAF exposed oysters had overall slightly lower mean values than control oysters, but over the 33-day recovery period the means differed only on day 2 ( $p=0.045$; Figure $5 \mathrm{~A})$. 
A

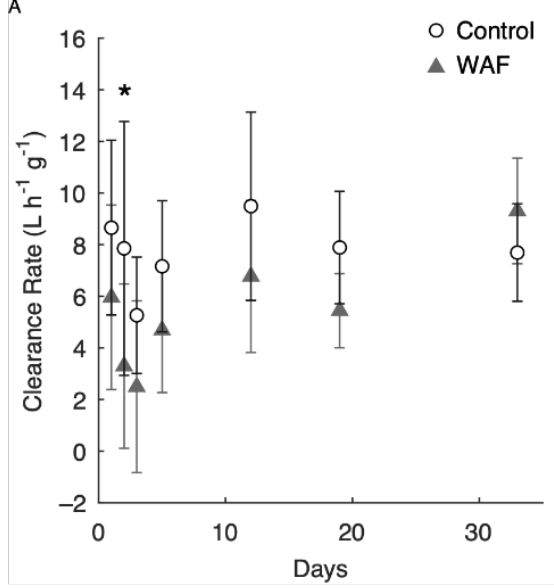

B

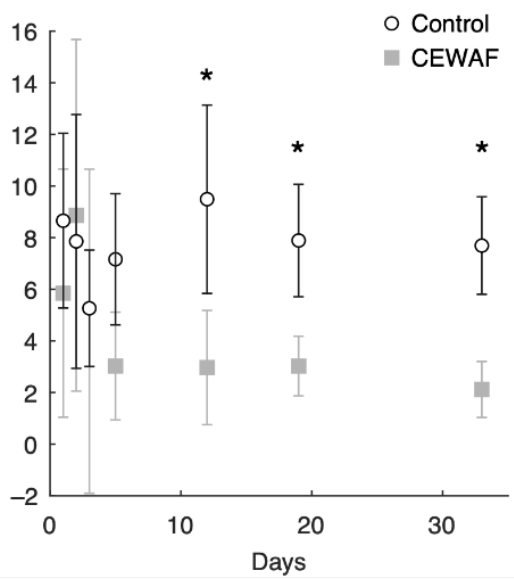

Figure 5. Mean clearance rates observed of adult oysters ( $n=6$ per treatment) after acute exposure to (A) WAF (100 $\mu \mathrm{L} \mathrm{L}^{-1}$ crude oil) or (B) CEWAF (100 $\mu \mathrm{L} \mathrm{L}^{-1}$ crude oil with $5 \mu \mathrm{L} \mathrm{L}^{-1}$ chemical dispersant) for $24 \mathrm{~h}$, and then returned to clean water for the duration of the experiment. Feeding experiments were conducted in clean water after initial exposure. Error bars represent standard deviations. Stars $\left(^{*}\right)$ denote significant differences between control and treatment clearance rates.

Oysters that were initially exposed to a $24 \mathrm{~h}$ CEWAF treatment exhibited clearance rates that were significantly lower after day 5 of the experimental trial $(p=0.004,0.044$, and 0.001 for days 12 , 19, and 33; Figure 5B). After 33 days, the depressed clearance rates of the CEWAF exposed oysters showed no sign of recovery with CEWAF exposed oysters clearing less than three times the water volume of control oysters (Figure 5B).

\section{Discussion}

\subsection{Veliger and Pediveliger Inactivity}

In this study, we found that the younger veliger stage had a smaller proportion of inactive individuals than the more developed pediveliger stages after exposure to WAF or CEWAF (Figure 2). These results differ from the general consensus in the literature where early life history stages display greater mortality/inactivity to pollutants compared to later staged organisms [21,22,41-43] and suggest that greater attention should be paid to later developmental stages in oysters. Several studies have investigated effects of oil and dispersant exposures on C. viriginica at different larval stages [15,16,28-32]. However, in most of these studies regardless of the larval stage examined exposures began shortly after fertilization (4-48 h) [15,30-32], making it difficult to assess the sensitivity of a given larval stage due to the confounding effects, such as variable exposure duration and lingering effects from exposure at earlier life stages. One study by Vignier et al. found increased mortality, slower shell growth, and reduced settlement following 72-96 h exposures of veliger and pediveliger C. virginica larvae to WAF, CEWAF, and WAF produced with Corexit alone [16]. They concluded that all larval stages were affected by exposures, though veligers were somewhat more sensitive than pediveligers. Laramore et al. found that mortality increased during long-term WAF exposures (up to $96 \mathrm{~h}$ ) of early but not late-stage $C$. viriginica veligers but that long-term CEWAF exposure increased mortality for both stages [29]. Discrepancies between our results and those of Vignier et al. and Laramore et al. may be due in part to differences in exposure methods. For example, the concentrations of the WAFs used in this study (8.5-84.5 $\left.\mathrm{mg} \mathrm{L}^{-1}\right)$ were generally lower than those used by Vignier et al. $\left(62.5-2000 \mathrm{mg} \mathrm{L}^{-1}\right)$ and Laramore et al. (100-1200 $\left.\mathrm{mg} \mathrm{L}^{-1}\right)$, and Vignier et al. used a high-energy water accommodated fraction (HEWAF) preparation method and performed exposures for $96 \mathrm{~h}$ as compared to our $24 \mathrm{~h}$ exposures. Sublethal effects, such as decreased growth rates, have been recorded for larval oysters that were exposed at earlier life stages to oil pollution for longer durations (48-96 h) than those in this study $[15,16,29-31,44,45]$. 
Although we observed no mortality in this study (all inactive larvae had active heartbeats), inactivity, even if just for a short time, can quickly lead to death if an individual sinks out of the water column or is otherwise unable to perform functions required for survival. Based on this result, it is apparent that the timing of oil exposure relative to life history stage is a critical factor affecting potential impacts on larval populations. Given that $50 \%$ of the exposed pediveligers were inactive after their settlement period (Figure 2B), oil pollution may potentially induce a bottleneck effect on oyster populations if this developmental stage is abundant during a significant oiling event. It is important to note that while many larval oysters do not become inactive after brief exposure to sublethal concentrations of crude oil or crude oil with chemical dispersants, surviving pediveligers may still be at an enhanced risk of death. This is because oil pollution can delay metamorphosis and ultimately extend the planktonic stage [46].

\subsection{Veliger Swimming}

For planktotrophic larvae like oysters, effective swimming and other coordinated appendage movements are critical for successfully feeding, avoiding predators, and seeking suitable habitats for settlement. Exposure to oil pollution at concentrations lower than those tested in this experiment showed strong negative effects on swimming performance and growth of many zooplankton species, such as copepods [47,48] and barnacle larvae [49,50]. For example, copepods exposed to dispersed crude oil at concentrations as low as $1 \mu \mathrm{L} \mathrm{L}^{-1}$ for $48 \mathrm{~h}$ experienced significant declines in growth and swimming speeds [47] and showed signs of narcosis and loss of balance after WAF exposure [47,50,51]. Reductions in phytoplankton consumption and fecal pellet production have been observed for copepods exposed to crude oil [52,53], in which reduced swimming lowers prey encounter rates [54]. Oyster veligers appeared to be quite resistant to acute exposure of soluble fractions of crude oil and chemical dispersant, as we found no significant differences in swimming behavior (Figure 1). This is consistent with other bivalve species, which have been found to be less vulnerable than other taxa to sublethal concentrations of oil pollution [30].

Given that no significant differences in cruising or sinking speeds were detected between control and oil exposed veligers (Figure 1A,B) after $24 \mathrm{~h}$ exposures to a wide array of crude oil concentrations (10-100 $\left.\mu \mathrm{L} \mathrm{L}^{-1}\right)$, individuals able to withstand initial non-lethal doses of WAF or CEWAF would likely be able to orient in the water column [55], to feed normally, and to develop to competency. This is supported by a study in which Laramore et al. exposed eastern oyster veligers to a sublethal CEWAF concentration $\left(20 \mu \mathrm{L} \mathrm{L}^{-1}\right)$ for $24 \mathrm{~h}$ then monitored growth for 3 weeks in clean water [29]. The results indicated that there were no severe impacts on development. However, following exposure to pollutants, some oyster veligers have been observed to show evidence of modified behaviors, such as quickly retracting their velum, which causes their valves to close and results in a dramatic sinking behavior [56]. In some cases, the valves shut before the velum had completely retracted, resulting in an exposed and protruding velum, which could lead to long-term reductions in feeding efficiency $[16,56]$.

\subsection{Pediveliger Settlement}

Although indicators of larval health can be observed by examining growth, development, or activity measurements, Langdon et al. argued settlement success was a better indicator of potential stress of meroplankton because it involves a critically and energetically costly metamorphic change [31]. The irreversible process of settlement for bivalves involves ending the planktonic life cycle phase and transitioning into a sessile adult. Functionality at the pediveliger stage is particularly important because pediveligers must actively respond to settlement cues in order to seek suitable benthic habitats [57]. During this period, both internal and external morphological alterations occur as crucial organs are rearranged for life as a sessile adult [58]. Given the numerous and complex modifications that occur, crude oil pollution has the potential to disrupt a number of physiological processes required for successful metamorphosis. Competent pediveligers exposed to oil pollution for $24 \mathrm{~h}$ in this study had significantly reduced settlement compared to control pediveligers (Figure 3). Decreased settlement has 
also been observed in pediveligers when exposed to WAF and CEWAF for $72 \mathrm{~h} \mathrm{[16],} \mathrm{but} \mathrm{here} \mathrm{we} \mathrm{show}$ that negative effects can occur at lower concentrations and shorter exposure durations. We observed that increasing concentrations of crude oil caused a stronger negative effect on settlement success of pediveligers but did not find an additional synergistic effect with the addition of chemical dispersant (Figure 3). This result suggests larval oysters may not be as susceptible as other marine invertebrates to the strong increase in toxicological effects when dispersant is added to crude oil [25].

Another potential inhibitor to settlement success in the natural environment (not tested in this study) is the presence of an oily film on oyster shells. Previous studies found that shells with an oil film were not suitable for pediveliger settlement and resulted in decreased spat abundance [59]. Given the location of most oyster reefs in shallow subtidal and low intertidal zones, the potential for oiling of the substrate as well as the water column may result in a stronger negative affect on larval settlement than indicated in this study. Large reductions in spat recruitment could ultimately lead to a decrease in adult populations.

\subsection{Adult Clearance Rates}

Adult oysters, like other sessile animals, cannot move away from a toxicant and are thus especially vulnerable to crude oil pollution. When feeding experiments were conducted in the same oiled conditions as the initial exposure, we found that clearance rates of individuals exposed for $24 \mathrm{~h}$ to WAF or CEWAF were significantly lower than those for individuals in the control (Figure 4A). Previous studies have reported reduced feeding rates for bivalves exposed to crude oil and its byproducts [26,60-62]. Axiak and George [60] attributed decreases in clearance rates following exposure to WAF to decreased pumping by the lateral cilia. In addition, mussels exposed to crude oil have been shown to have reduced valve gape and to spend more time closed than control mussels [63].

Results of the 33-day exposure experiment suggest that there may be lingering effects after acute exposures that are not detected after only $24 \mathrm{~h}$. Oysters exposed to a combination of crude oil and chemical dispersant did not recover to clearance rates comparable to controls after 33 days, even when maintained continuously in clean seawater (Figure 5B). In contrast, oysters exposed to only crude oil did not exhibit a difference in clearance rates after the 33-day trial (Figure 5A). These results appear to suggest a synergistic effect of crude oil and chemical dispersants. The presence of chemical dispersants has been shown to increase the solubility $[23,64]$ and bioavailability $[65,66]$ of PAHs and to increase the proportion of high molecular weight PAHs in solution $[23,64]$. High molecular weight PAHs are more toxic and persistent than lower molecular weight PAHs [23] and have been shown to reduce clearance rates at lower concentrations [61]. PAHs can be retained in the lipid pools of internal tissues up to 2 months after exposure [67], which may help to explain our observation of reduced clearance rates 33 days after an acute CEWAF exposure. Additional clearance rate studies may ultimately be required to determine if recovery is possible for oysters if given longer recovery times.

In order to determine if the decreased feeding response was due to the presence of WAF or CEWAF in the water column itself, adult oysters were also fed in clean seawater after an initial $24 \mathrm{~h}$ exposure to soluble fractions of crude oil and chemical dispersant. When oysters were allowed to feed in clean seawater conditions after their initial oil exposure, they exhibited clearance rates similar to or somewhat higher than those of the controls (Figure 4B). This scenario represents a situation where an oil spill occurs then is rapidly diluted due to tidal and/or wind driven mixing. An increase in clearance rates after oil exposure, such as observed here for the $50 \mu \mathrm{L} \mathrm{L}^{-1}$ (and possibly the $100 \mu \mathrm{L} \mathrm{L}^{-1}$ ) CEWAF treatments, has been attributed to compensation for decreased feeding performed in the presence of oil [26].

\section{Conclusions}

The present study examined sublethal effects, which occur at various life history stages, on the eastern oyster and provided insights into potential impacts on oyster populations after an oil spill. No significant negative impacts to oyster veliger swimming kinematics were observed. However, there was a significant decrease in settlement of pediveligers exposed to realistic concentrations of 
soluble fractions of crude oil and chemical dispersant. The result that late-stage oyster pediveligers were more strongly impacted than early-stage veligers is contrary to the findings of many other studies that suggest the earliest life history stages are most susceptible. It is thus important to consider that in oysters the effects of oil exposure may not be manifested until a later developmental stages when metamorphosis should occur. Events that cause substantial reduction in late staged larvae may cause a bottleneck effect for future oyster populations.

Adult oysters can be used as a bio-indicator for the health and recovery of estuarine ecosystems after an oil spill. Non-invasive measurements such as clearance rates can help signify if adult oysters have recovered from oil pollution. Impacts to adult populations can also influence the reproductive output available to support future generations. Reduced clearance rates due to the addition of chemical dispersants may have negative impacts on the surrounding marine environment. After acute exposures to crude oil and chemical dispersants adult $C$. virginica can exhibit lasting effects on feeding performance. Such results should be considered by emergency responders to oil spills in order to minimize impacts to both future adult oyster populations and the marine environment. The consequences of reduced oyster populations after an oil spill can severely impact economically and ecologically significant coastal ecosystems.

Author Contributions: Conceptualization, S.M.G. and B.J.G.; Formal analysis, S.M.G.; Funding acquisition, B.J.G.; Investigation, S.M.G. and O.H.H.; Methodology, S.M.G. and B.J.G.; Project administration, B.J.G.; Software, K.T.D.C.; Supervision, B.J.G.; Writing—original draft, S.M.G.; Writing—review and editing, K.T.D.C., O.H.H. and B.J.G. All authors have read and agreed to the published version of the manuscript.

Funding: This research was funded by The Gulf of Mexico Research Initiative: DROPPS II Consortium: Dispersion Research on Oil: Physics and Plankton Studies and an Alfred P. Sloan Foundation fellowship to B.J.G.

Acknowledgments: The authors thank Kathrene Lo for assisting with data analysis and Southern Cross and Research Aquaculture, Inc. for providing oyster larvae.

Conflicts of Interest: The authors declare no conflict of interest. The funders had no role in the design of the study; in the collection, analyses, or interpretation of data; in the writing of the manuscript, or in the decision to publish the results.

\section{References}

1. Graham, B.; Reilly, W.K.; Beinecke, F.; Boesch, D.F.; Garcia, T.D.; Murray, C.A.; Ulmer, F. Deep Water: The Gulf Oil Disaster and the Future of Offshore Drilling; Report to the President; National Commission on the BP Deepwater Horizon Oil Spill and Offshore Drilling: Washington, DC, USA, 2011; pp. 1-398. Available online: https://digital.library.unt.edu/ark:/67531/metadc123527 (accessed on 10 October 2020).

2. Nixon, Z.; Zengel, S.; Michel, J. NOAA Technical Report: Categorization of Shoreline Oiling from the Deepwater Horizon Oil Spill; Research Planning Inc.: Columbia, SC, USA, 2015. Available online: https://www.fws.gov/ doiddata/dwh-ar-documents/901/DWH-AR0270684.pdf (accessed on 10 October 2020).

3. Zukunft, P.F. Summary Report for SubSea and SubSurface Oil and Dispersant Detection: Sampling and Monitoring; DIANE Publishing: Darby, PA, USA, 2010. Available online: https://www.restorethegulf.gov/sites/default/ files/documents/pdf/osat_report_final_17dec.pdf (accessed on 10 October 2020).

4. Li, Z.; Lee, K.; King, T.; Boufadel, M.C.; Venosa, A.D. Assessment of chemical dispersant effectiveness in a wave tank under regular non-breaking and breaking wave conditions. Mar. Pollut. Bull. 2008, 56, 903-912. [CrossRef] [PubMed]

5. Kujawinski, E.B.; Soule, M.C.K.; Valentine, D.L.; Boysen, A.K.; Longnecker, K.; Redmond, M.C. Fate of Dispersants Associated with the Deepwater Horizon Oil Spill. Environ. Sci. Technol. 2011, 45, 1298-1306. [CrossRef] [PubMed]

6. Reddy, C.M.; Arey, J.S.; Seewald, J.S.; Sylva, S.P.; Lemkau, K.L.; Nelson, R.K.; Carmichael, C.A.; McIntyre, C.P.; Fenwick, J.; Ventura, G.T.; et al. Composition and fate of gas and oil released to the water column during the Deepwater Horizon oil spill. Proc. Natl. Acad. Sci. USA 2012, 109, 20229-20234. [CrossRef] [PubMed]

7. Harry, H. Oysters of the northwestern Gulf of Mexico. Tex. Conchol. 1985, 23, 14-19. 
8. Grabowski, J.H.; Brumbaugh, R.D.; Conrad, R.F.; Keeler, A.G.; Opaluch, J.J.; Peterson, C.H.; Piehler, M.F.; Powers, S.P.; Smyth, A.R. Economic Valuation of Ecosystem Services Provided by Oyster Reefs. Bioscience 2012, 62, 900-909. [CrossRef]

9. Peterson, C.; Grabowski, J.; Powers, S. Estimated enhancement of fish production resulting from restoring oyster reef habitat: Quantitative valuation. Mar. Ecol. Prog. Ser. 2003, 264, 249-264. [CrossRef]

10. Tews, J.; Brose, U.; Grimm, V.; Tielbörger, K.; Wichmann, M.C.; Schwager, M.; Jeltsch, F. Animal species diversity driven by habitat heterogeneity/diversity: The importance of keystone structures. J. Biogeogr. 2003, 31, 79-92. [CrossRef]

11. Seed, R. Predator-prey relationships between the mud crab Panopeus herbstii, the blue crab, Callinectes sapidus and the Atlantic ribbed mussel Geukensia (=Modiolus) demissa. Estuar. Coast. Mar. Sci. 1980, 11, 445-458. [CrossRef]

12. Coen, L.D.; Luckenbach, M.W.; Breitburg, D.L. The role of oyster reefs as essential fish habitat: A review of current knowledge and some new perspectives. Am. Fish. Soc. Symp. 1999, 22, 438-454.

13. Butler, R.W.; Kirbyson, J.W. Oyster Predation by the Black Oystercatcher in British Columbia. Condor 1979, 81, 433. [CrossRef]

14. Berringan, M.; Candies, T.; Cirino, J.; Dugas, R.; Dyer, C.; Gray, J.; Herrington, T.; Keithly, W.; Leard, R.; Nelson, J.; et al. The Oyster Fishery of the Gulf of Mexico, United States: A Regional Management Plan; Gulf States Marine Fisheries Commission: Ocean Springs, MS, USA, 1991.

15. Vignier, J.; Donaghy, L.; Soudant, P.; Chu, F.L.E.; Morris, J.M.; Carney, M.W.; Lay, C.; Krasnec, M.; Robert, R.; Volety, A.K. Impacts of Deepwater Horizon oil and associated dispersant on early development of the Eastern oyster Crassostrea virginica. Mar. Pollut. Bull. 2015, 100, 426-437. [CrossRef]

16. Vignier, J.; Soudant, P.; Chu, F.; Morris, J.; Carney, M.; Lay, C.; Krasnec, M.; Robert, R.; Volety, A.K. Lethal and sub-lethal effects of Deepwater Horizon slick oil and dispersant on oyster (Crassostrea virginica) larvae. Mar. Environ. Res. 2016, 120, 20-31. [CrossRef] [PubMed]

17. Supan, J. Evaluation of a leased oyster bottom in Mississippi Sound. Gulf Caribb. Res. 1983, 7, $261-266$. [CrossRef]

18. Andrews, J. Mollusca: Pelecypods and Lesser Classes. In Reproduction of Marine Invertebrates; Giese, A., Pearse, J., Eds.; Academic Press: New York, NY, USA, 1979; pp. 293-341.

19. Newell, R.I.E.; Koch, E.W. Modeling seagrass density and distribution in response to changes in turbidity stemming from bivalve filtration and seagrass sediment stabilization. Estuaries 2004, 27, 793-806. [CrossRef]

20. Zu Ermgassen, P.S.E.; Spalding, M.D.; Grizzle, R.E.; Brumbaugh, R.D. Quantifying the Loss of a Marine Ecosystem Service: Filtration by the Eastern Oyster in US Estuaries. Estuaries Coasts 2013, 36, 36-43. [CrossRef]

21. Saiz, E.; Movilla, J.; Yebra, L.; Barata, C.; Calbet, A. Lethal and sublethal effects of naphthalene and 1,2-dimethylnaphthalene on naupliar and adult stages of the marine cyclopoid copepod Oithona davisae. Environ. Pollut. 2009, 157, 1219-1226. [CrossRef] [PubMed]

22. Almeda, R.; Wambaugh, Z.; Wang, Z.; Hyatt, C.; Liu, Z.; Buskey, E.J. Interactions between Zooplankton and Crude Oil: Toxic Effects and Bioaccumulation of Polycyclic Aromatic Hydrocarbons. PLoS ONE 2013, 8, e67212. [CrossRef] [PubMed]

23. Couillard, C.M.; Lee, K.; Légaré, B.; King, T.L. Effect of dispersant on the composition of the water-accommodated fraction of crude oil and its toxicity to larval marine fish. Environ. Toxicol. Chem. 2005, 24, 1496-1504. [CrossRef]

24. Pie, H.V.; Mitchelmore, C.L. Acute toxicity of current and alternative oil spill chemical dispersants to early life stage blue crabs (Callinectes sapidus). Chemosphere 2015, 128, 14-20. [CrossRef] [PubMed]

25. Rico-Martínez, R.; Snell, T.W.; Shearer, T.L. Synergistic toxicity of Macondo crude oil and dispersant Corexit 9500A ${ }^{\circledR}$ to the Brachionus plicatilis species complex (Rotifera). Environ. Pollut. 2013, 173, 5-10. [CrossRef]

26. Kim, M.-C.; Cho, S.-M.; Jeong, W.-G. Short-term physiological response of the Pacific oyster, Crassostrea gigas, on exposure to varying levels of polycyclic aromatic hydrocarbon. Aquac. Res. 2007, 38, 1612-1618. [CrossRef]

27. Sigler, M.; Leibovitz, L. Acute toxicity of oil and bilge cleaners to larval American oysters (Crassostrea virginica). Bull. Environ. Contam. Toxicol. 1982, 29, 137-145. [CrossRef] [PubMed]

28. Laramore, S.; Krebs, W.; Garr, A. Effects of Macondo Canyon 252 Oil (Naturally and Chemically Dispersed) on Larval Crassostrea virginica (Gmelin, 1791). J. Shellfish. Res. 2014, 33, 709-718. [CrossRef] 
29. Stefansson, E.S.; Langdon, C.J.; Pargee, S.M.; Blunt, S.M.; Gage, S.J.; Stubblefield, W.A. Acute effects of non-weathered and weathered crude oil and dispersant associated with the Deepwater Horizon incident on the development of marine bivalve and echinoderm larvae. Environ. Toxicol. Chem. 2016, 35, 2016-2028. [CrossRef]

30. Langdon, C.; Stefansson, E.S.; Pargee, S.M.; Blunt, S.M.; Gage, S.J.; Stubblefield, W.A. Chronic effects of non-weathered and weathered crude oil and dispersant associated with the Deepwater Horizon incident on development of larvae of the eastern oyster, Crassostrea virginica. Environ. Toxicol. Chem. 2016, 35, 2029-2040. [CrossRef]

31. Finch, B.E.; Stefansson, E.S.; Langdon, C.J.; Pargee, S.M.; Blunt, S.M.; Gage, S.J.; Stubblefield, W.A. Photo-enhanced toxicity of two weathered Macondo crude oils to early life stages of the eastern oyster (Crassostrea virginica). Mar. Pollut. Bull. 2016, 113, 316-323. [CrossRef] [PubMed]

32. Bacosa, H.P.; Erdner, D.L.; Liu, Z. Differentiating the roles of photooxidation and biodegradation in the weathering of Light Louisiana Sweet crude oil in surface water from the Deepwater Horizon site. Mar. Pollut. Bull. 2015, 95, 265-272. [CrossRef]

33. Aurand, D.; Coelho, G. Cooperative Aquatic Toxicity Testing of Dispersed Oil and the Chemical Response to Oil Spills: Ecological Effects Research Forum (CROSERF); Technical Report 07-03; Ecosystem Management \& Associates, Inc.: Lusby, MD, USA, 2005.

34. Barron, M.G.; Ka'Aihue, L. Critical evaluation of CROSERF test methods for oil dispersant toxicity testing under subarctic conditions. Mar. Pollut. Bull. 2003, 46, 1191-1199. [CrossRef]

35. Clark, J.R.; Bragin, G.E.; Febbo, E.J.; Letinski, D.J. Toxicity of physically and chemically dispersed oils under continuous and environmentally realistic exposure conditions: Applicability to dispersant use decisions in spill response planning. In Proceedings of the International Oil Spill Conference (IOSC 2001, No. 2), Tampa, FL, USA, 26-29 March 2001; pp. 1249-1255.

36. Singer, M.; Aurand, D.; Bragin, G.; Clark, J.; Coelho, G.; Sowby, M.; Tjeerdema, R. Standardization of the Preparation and Quantitation of Water-accommodated Fractions of Petroleum for Toxicity Testing. Mar. Pollut. Bull. 2000, 40, 1007-1016. [CrossRef]

37. Singer, M.M.; Aurand, D.V.; Coelho, G.M.; Bragin, G.E.; Clark, J.R.; Sowby, M.; Tjeerdema, R.S. Making, measuring, and using water-accommodated fractions of petroleum for toxicity testing. In Proceedings of the International Oil Spill Conference (IOSC 2001, No. 2), Tampa, FL, USA, March 2001; pp. 1269-1274.

38. Law, R.; Dawes, V.; Woodhead, R.; Matthiessen, P. Polycyclic aromatic hydrocarbons (PAH) in seawater around England and Wales. Mar. Pollut. Bull. 1997, 34, 306-322. [CrossRef]

39. Dupuy, C.; Le Gall, S.; Hartmann, H.; Bréret, M. Retention of ciliates and flagellates by the oyster Crassostrea gigas in French Atlantic coastal ponds: Protists as a trophic link between bacterioplankton and benthic suspension-feeders. Mar. Ecol. Prog. Ser. 1999, 177, 165-175. [CrossRef]

40. Mo, C.; Neilson, B. Standardization of oyster soft tissue dry weight measurements. Water Res. 1994, 28, 243-246. [CrossRef]

41. Riisgård, H.U. Efficiency of particle retention and filtration rate in 6 species of Efficiency of particle retention and filtration rate in 6 species of Northeast American bivalves. Mar. Ecol. Prog. Ser. 1988, 45, 217-223. [CrossRef]

42. George-Ares, A.; Clark, J. Aquatic toxicity of two Corexit ${ }^{\circledR}$ dispersants. Chemosphere 2000, 40, 897-906. [CrossRef]

43. Goodbody-Gringley, G.; Wetzel, D.L.; Gillon, D.; Pulster, E.; Miller, A.; Ritchie, K.B. Toxicity of Deepwater Horizon Source Oil and the Chemical Dispersant, Corexit ${ }^{\circledR}$ 9500, to Coral Larvae. PLoS ONE 2013, 8, e45574. [CrossRef]

44. Salehi, M.; Rodriguez, R.; Boettcher, A.; Powers, S.P.; Geitner, N.; Ladner, D.A.; Rikard, S.; Whelton, A.J. Impact of dispersant on early life stages of the water flea Daphnia magna and the eastern oyster Crassostrea virginica. J. Appl. Toxicol. 2017, 37, 1464-1470. [CrossRef]

45. Jeong, W.-G.; Cho, S.-M. The effects of polycyclic aromatic hydrocarbon exposure on the fertilization and larval development of the Pacific oyster, Crassostrea gigas. J. Shellfish Res. 2005, 24, 209-213.

46. Beiras, R.; His, E. Effects of dissolved mercury on embryo-genesis, survival, growth and metamorphosis of Crassostrea gigas oyster larvae. Mar. Ecol. Prog. Ser. 1994, 113, 95-103. [CrossRef]

47. Almeda, R.; Connelly, T.L.; Buskey, E.J. How much crude oil can zooplankton ingest? Estimating the quantity of dispersed crude oil defecated by planktonic copepods. Environ. Pollut. 2016, 208, 645-654. [CrossRef]

48. Jiang, Z.; Huang, Y.; Chen, Q.; Zeng, J.; Xu, X. Acute toxicity of crude oil water accommodated fraction on marine copepods: The relative importance of acclimatization temperature and body size. Mar. Environ. Res. 2012, 81, 12-17. [CrossRef] 
49. Almeda, R.; Connelly, T.L.; Buskey, E.J. Novel insight into the role of heterotrophic dinoflagellates in the fate of crude oil in the sea. Sci. Rep. 2014, 4, 7560. [CrossRef] [PubMed]

50. Donahue, W.; Wang, R.T.; Welch, M.; Nicol, J. Effects of water-soluble components of petroleum oils and aromatic hydrocarbons on barnacle larvae. Environ. Pollut. 1977, 13, 187-202. [CrossRef]

51. Cohen, J.H.; McCormick, L.R.; Burkhardt, S.M. Effects of Dispersant and Oil on Survival and Swimming Activity in a Marine Copepod. Bull. Environ. Contam. Toxicol. 2014, 92, 381-387. [CrossRef] [PubMed]

52. Hansen, B.H.; Altin, D.; Olsen, A.J.; Nordtug, T. Acute toxicity of naturally and chemically dispersed oil on the filter-feeding copepod Calanus finmarchicus. Ecotoxicol. Environ. Saf. 2012, 86, 38-46. [CrossRef] [PubMed]

53. Hansen, B.H.; Altin, D.; Nordtug, T.; Øverjordet, I.B.; Olsen, A.J.; Krause, D.; Størdal, I.; Størseth, T.R. Exposure to crude oil micro-droplets causes reduced food uptake in copepods associated with alteration in their metabolic profiles. Aquat. Toxicol. 2017, 184, 94-102. [CrossRef] [PubMed]

54. Titelman, J.; Kiørboe, T. Motility of copepod nauplii and implications for food encounter. Mar. Ecol. Prog. Ser. 2003, 247, 123-135. [CrossRef]

55. Dekshenieks, M.M.; Hofmann, E.E.; Klinck, J.M.; Powell, E.N. Modeling the vertical distribution of oyster larvae in response to environmental conditions. Mar. Ecol. Prog. Ser. 1996, 136, 97-110. [CrossRef]

56. Wisely, B.; Blick, R. Mortality of marine invertebrate larvae in mercury, copper, and zinc solutions. Mar. Freshw. Res. 1967, 18, 63-72. [CrossRef]

57. Finelli, C.M.; Wethey, D.S. Behavior of oyster (Crassostrea virginica) larvae in flume boundary layer flows. Mar. Biol. 2003, 143, 703-711. [CrossRef]

58. Baker, S.; Mann, R. Description of metamorphic phases in the oyster Crassostrea virginica and effects of hypoxia on metamorphosis. Mar. Ecol. Prog. Ser. 1994, 104, 91-99. [CrossRef]

59. Smith, C.M.; Hackney, C.T. The Effects of Hydrocarbons on the Setting of the American Oyster, Crassostrea virginica, in Intertidal Habitats in Southeastern North Carolina. Estuaries 1989, 12, 42-48. [CrossRef]

60. Axiak, V.; George, J.J. Effects of exposure to petroleum hydrocarbons on the gill functions and ciliary activities of a marine bivalve. Mar. Biol. 1987, 94, 241-249. [CrossRef]

61. Donkin, P.; Widdows, J.; Evans, S.V.; Worrall, C.M.; Carr, M. Quantitative structure-activity relationships for the effect of hydrophobic organic chemicals on rate of feeding by mussels (Mytilus edulis). Aquat. Toxicol. 1989, 14, 277-293. [CrossRef]

62. Toro, B.; Navarro, J.; Palma-Fleming, H. Use of clearance rate in Choromytilus chorus (Bivalvia: Mytilidae) as a non-destructive biomarker of aquatic pollution. Rev. Chil. Hist. Nat. 2003, 76, 267-274. [CrossRef]

63. Redmond, K.J.; Berry, M.; Pampanin, D.M.; Andersen, O.K. Valve gape behaviour of mussels (Mytilus edulis) exposed to dispersed crude oil as an environmental monitoring endpoint. Mar. Pollut. Bull. 2017, 117, 330-339. [CrossRef]

64. Yamada, M.; Takada, H.; Toyoda, K.; Yoshida, A.; Shibata, A.; Nomura, H.; Wada, M.; Nishimura, M.; Okamoto, K.; Ohwada, K. Study on the fate of petroleum-derived polycyclic aromatic hydrocarbons (PAHs) and the effect of chemical dispersant using an enclosed ecosystem, mesocosm. Mar. Pollut. Bull. 2003, 47, 105-113. [CrossRef]

65. Wolfe, M.; Schwartz, G.; Singaram, S.; E Mielbrecht, E.; Tjeerdema, R.S.; Sowby, M.L. Influence of dispersants on the bioavailability and trophic transfer of petroleum hydrocarbons to larval topsmelt (Atherinops affinis). Aquat. Toxicol. 2001, 52, 49-60. [CrossRef]

66. Wu, D.; Wang, Z.; Hollebone, B.; McIntosh, S.; King, T.; Hodson, P.V. Comparative toxicity of four chemically dispersed and undispersed crude oils to rainbow trout embryos. Environ. Toxicol. Chem. 2012, 31, 754-765. [CrossRef]

67. Soniat, T.M.; King, S.M.; Tarr, M.A.; Thorne, M.A. Chemical and Physiological Measures on Oysters (Crassostrea virginica) from Oil-Exposed Sites in Louisiana. J. Shellfish. Res. 2011, 30, 713-717. [CrossRef]

Publisher's Note: MDPI stays neutral with regard to jurisdictional claims in published maps and institutional affiliations. 